\title{
EFFECTS OF REPEATED SPRINT TRAINING ON ISOCAPNIC BUFFERING PHASE IN VOLLEYBALL PLAYERS
}

\author{
EFEITOS DE TREINOS DE SPRINT REPETIDOS NA FAIXA DE TAMPONAMENTO ISOCÁPNICO \\ EM JOGADORES DE VOLEIBOL \\ EFECTOS DEL ENTRENAMIENTO DE SPRINTREPETIDO EN LA FASE DE TAMPONAMIENTO \\ ISOCÁPNICO EN JUGADORES DE VOLEIBOL
}

Original Article

Artigo OrIGINAL

Artículo Original

\author{
SelcenKormaz Erylmaz' \\ (Physical Education Professional) \\ Kerimhan Kaynak ${ }^{2}$ \\ (Physical Education Professional) \\ Metin Polat ${ }^{2}$ \\ (Physical Education Professional) \\ Sami Aydoğan ${ }^{3}$ \\ (Physiologist)
}

1. Cukurova University, School of Physical Education and Sports, Balcalı, Adana, Turkey. 2. Erciyes University, School of Physical Education and Sports, Kayseri, Turkey.

3. Erciyes University, Faculty of Medicine, Department of Physiology, Division of Sports Physiology, Kayseri, Turkey.

\section{Correspondence:}

Cukurova University, School of Physical Education and Sports, Balcall, Sarıçam, Adana, Turkey, 1380.selcen_korkmaz@yahoo.com

\section{ABSTRACT}

Introduction: The region between the ventilatory threshold (VT) and respiratory compensation point (RCP) is defined as the isocapnic buffering (ICB) phase and represents a phase of compensation for exercise-induced metabolic acidosis. There is sparse literature examining the effects of physical training on ICB phase in athletes. Objectives: The purpose of this study was to examine the effects of a repeated sprint training program on the ICB phase of college volleyball players. Methods: Eighteen male volleyball players were randomly assigned to either an experimental group $(n=9)$ or a control group $(n=9)$ and followed a traditional volleyball training program three times per week for six weeks. The experimental group additionally performed a repeated sprint training protocol immediately before each volleyball training session. Before and after the 6-week training period, all participants performed an incremental treadmill test to determine $V T, R C P$, and maximal oxygen uptake $\left(\mathrm{VO}_{2 \text { max }}\right)$. The ICB phases were calculated as $\mathrm{VO}_{2}(\mathrm{ml} / \mathrm{kg} / \mathrm{min})$ and sprint speed $(\mathrm{km} / \mathrm{h})$. Results: The experimental group showed significant improvements in ICB phase, $\mathrm{RCP}, \mathrm{VO}_{2 \max }$ and maximal sprint speed after training $(p<0.01)$. There were no significant changes in VT after training in the experimental group ( $p>0.05)$. None of these variables changed significantly in the control group ( $p>0.05)$. Conclusions: These findings indicate that repeated sprint training can enhance the ICB phase of volleyball players, which may be attributable to an improvement in buffering capacity leading to a shift in RCP towards higher intensities without any change in VT. The increase in the ICB phase may an important factor in terms of improvement in the high-intensity exercise tolerance of athletes. Level of Evidence ll; Therapeutic studies - Investigating the results of treatment.

Keywords: Oxygen consumption; Anaerobic threshold; Hyperventilation; Acidosis.

\section{RESUMO}

Introdução: a região entre o limiar ventilatório (VT) e o ponto de compensação respiratório (RCP) é definido como faixa de temporamento isocápnico (ICB) e representa a fase de compensação para a acidose metabólica induzida por exercício. Há escassa literatura examinando os efeitos do treinamento físico na fase ICB em atletas. Objetivos: 0 objetivo desse estudo foi examinar os efeitos do programa de treinamento de Srint repetido na fase ICB em jogadores universitários de voleibol. Métodos: dezoito jogadores homens de voleibol foram aleatoriamente designados para um grupo experimental $(n=9)$ ou um grupo controle $(n=9)$ e completaram um programa tradicional de treinamento de voleibol três vezes por semana, durante seis semanas. O grupo experimental, adicionalmente, realizou um protocolo de treinamento de sprint repetido imediatamente antes de cada sessão de treinamento de voleibol. Antes e após o período de treinamento de 6 semanas, todos os participantes realizaram um teste de esteira experimental para determinar VT, RCP e consumo máximo de oxigênio $\left(\mathrm{VO}_{2 \max }\right)$. As fases ICB foram calculadas como VO $(\mathrm{ml} / \mathrm{kg} / \mathrm{min})$ e velocidade de corrida ( $\mathrm{km} / \mathrm{h}$ ). Resultados: o grupo experimental mostrou melhorias significativas na fase ICB, RCP, $V \mathrm{O}_{2 \max }$ e velocidade de corrida máxima depois do treino $(p<0.01)$. Não houve mudanças significativas no VT após o treino no grupo experimental $(p>0.05$ ). Nenhuma das variáveis mudou significativamente no grupo controle ( $p$ $>0.05$ ). Conclusões: a partir desses resultados, concluímos que o treinamento de Sprint repetido pode realçar a fase ICB em jogadores de voleibol, que podem ser atribuídos à melhora do efeito tampão, levando ao deslocamento da $R C P$ para intensidades mais altas, sem nenhuma mudança no VT. O aumento na fase ICB pode ser um fator importante em relação à melhora na tolerância ao exercício de alta intensidade em atletas. Nível de evidência ll, Estudos terapêuticos - Investigação dos resultados do tratamento.

Descritores: Consume de oxigênio, Liminar anaeróbio, Hiperventilação, Acidose.

\section{RESUMEN}

Introducción: la región comprendida entre el umbral de ventilación (UV) y el punto de compensación respiratoria $(P C R)$ se define como la fase de amortiguación isocapnica (ICB) y representa una fase de compensación de la acidosis metabólica inducida por el ejercicio. Hay poca literatura que examine los efectos del entrenamiento físico en la fase ICB de los atletas. Objetivos: El propósito de este estudio fue examinar los efectos del programa de entrenamiento de sprints repetidos en la fase ICB de los jugadores de voleibol de la universidad. Métodos: Dieciocho jugadores de 
voleibol masculino fueron asignados aleatoriamente a un grupo experimental $(n=9)$ o un grupo de control $(n=9)$ y completaron un programa tradicional de entrenamiento de voleibol, tres veces por semana durante 6 semanas. El grupo experimental también realizó un protocolo de entrenamiento de sprint repetido inmediatamente antes de cada sesión de entrenamiento de voleibol. Antes y después del período de entrenamiento de 6 semanas, todos los participantes realizaron una prueba incremental en cinta rodante para determinar UV, RCP y consumo máximo de oxígeno $\left(\mathrm{VO}_{2 \text { max }}\right.$. Las fases ICB se calcularon como VO $(\mathrm{ml} / \mathrm{kg} / \mathrm{min})$ y velocidad $(\mathrm{km} / \mathrm{h})$. Resultados: El grupo experimental mostró mejoras significativas en la fase ICB, $R C P, V O_{2 \max } y$ velocidad de carrera máxima post entrenamiento ( $p$ $<0.01$ ). No hubo cambios significativos en UV después del entrenamiento en el grupo experimental ( $p>0.05$ ). Ninguna de estas variables cambió significativamente en el grupo control ( $p>0.05)$. Conclusiones: A partir de estos resultados, concluimos que el entrenamiento de sprints repetidos puede mejorar la fase ICB de los jugadores de voleibol, lo que puede atribuirse a la mejora de la capacidad de amortiguación que lleva al cambio de RCP a intensidades más altas sin ningún cambio en el UV. El aumento en la fase ICB puede ser un factor importante en relación con la mejora en la tolerancia al ejercicio de alta intensidad en atletas. Nivel de Evidencia ll; Estudios terapéuticos - Investigando resultados del tratamiento.

Palabras Clave: Consumo de oxígeno; Umbral anaeróbico; Hiperventilación; Acidosis.

\section{INTRODUCTION}

During incremental exercise, anaerobic threshold (AT) can be determined from non-invasive gas exchange measurements alternative to the measurements of blood lactate concentration, in this case referred to as the ventilatory threshold (VT). ${ }^{1} \mathrm{VT}$ corresponds to the nonlinear increase in carbon dioxide production and ventilation due to the bicarbonate buffering of hydrogen ions $\left(\mathrm{H}^{+}\right)$in response to the systematic increase of blood lactate above resting values. ${ }^{2}$ When $\mathrm{H}^{+}$can no longer be compensated by circulating bicarbonate leads to a decrease in blood $\mathrm{pH}$ and stimulates the carotid bodies to increase ventilatory drive results in hyperventilation. ${ }^{2}$ This additional ventilatory response is called the respiratory compensation point (RCP). ${ }^{3}$ The region between AT and $\mathrm{RC}$ is defined as isocapnic buffering (ICB) phase. ${ }^{4}$ The region between RCP and the end of exercise is defined as the phase of hypocapnic hyperventilation $(\mathrm{HHV})$. 5,6

A few researchers investigated effects of physical training on ICB phase in the endurance athletes, however, showed different results. ${ }^{5,7}$ Consistent with many studies, 8,9 we recently reported that the addition of a repeated sprint training (RST) program to normal volleyball training sessions can improve both the $\mathrm{VO}_{2 \max }$ and high-intensity intermittent exercise performance of college volleyball players. ${ }^{10}$ However, to our knowledge, there is no previous study examining the effects of RST on the ICB phase during incremental exercise. The purpose of this study was to examine the effects of a RST program on the ICB phase during incremental exercise in college volleyball players.

\section{METHODS}

Eighteen male volleyball players competing in Division I of the Turkish University League volunteered to participate in the study. All of the subjects were members of the Erciyes University volleyball team. All players had trained and competed regularly in volleyball for at least 4 years. The Erciyes University Ethics Committee approved the study (2016/651). All testing and training procedures were fully explained, and written informed consent was obtained for each subject. During the study, the players were not allowed to perform any additional conditioning training that would affect the results of the study.

The experimental protocol consisted of baseline testing, a 6-week training intervention, and post-testing. After baseline testing, 18 volleyball players were randomly divided into two equal groups: the experimental (EXG; mean \pm SD; age $21.2 \pm 1.3$ years, height $183.4 \pm 5.4 \mathrm{~cm}$, weight 71.1 $\pm 7.3 \mathrm{~kg}$ ) and control groups (CG; age $21.2 \pm 1.6$ years, height $184 \pm 4.4 \mathrm{~cm}$, weight $75.7 \pm 8.5 \mathrm{~kg}$ ). Both groups followed a traditional volleyball training program three times per week for 6 weeks. All training sessions in both groups were conducted at the same time of day on Monday, Wednesday and Friday of each consecutive week. The experimental group additionally performed RST prior to their normal volleyball training sessions.

Maximal oxygen uptake $\left(\mathrm{VO}_{2 \max }\right), \mathrm{VT}$ and $\mathrm{RCP}$ were determined from a progressive intensity and continuous effort treadmill protocol. All tests were performed on a motorized treadmill (h/p/Cosmos Quasar med, Nussdorf-Traunstein, Germany). $\mathrm{VO}_{2}, \mathrm{VCO}_{2}$ and VE were measured online using a breath-by-breath cardiopulmonary exercise testing system (Quark PFT Ergo, CosmedSrl, Rome, Italy). Breath-by-breath data was smoothed using a five-step average filter and then reduced to 15 s stationary averages.

Players started running at $7 \mathrm{~km} / \mathrm{h}$ with speed increments of $1 \mathrm{~km} / \mathrm{h}$

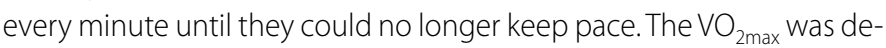
fined as the highest $15 \mathrm{sVO}_{2}$ value reached during the incremental test and expressed as a relative value (milliliters per minute per body mass; $\mathrm{ml}$ / $\mathrm{kg} / \mathrm{min})$. Achievement of $\mathrm{VO}_{2 \max }$ was considered as the attainment of at least two of the following criteria: 1) a plateau in VO2 despite increasing speed, 2) a respiratory exchange ratio $\left(\mathrm{VCO}_{2} \mathrm{NO}_{2}\right)$ above 1.10 , and 3) a $\mathrm{HR}$ (heart rate) within 10 beats per minute of age-predicted maximum HR (220 - age). Time to exhaustion was recorded as the time from the start of the run until the point of exhaustion. Maximal respiratory exchange ratio $\left(R_{E} R_{\text {max }}\right)$ was express as the highest $15 \mathrm{~s}$ average value obtained during the last stage of the incremental exercise test.

The VT and RCP were determined using the $\mathrm{V}$-slope method described by Beaver et al. ${ }^{1}$ The $V T$ and $\mathrm{RCP}$ were defined as the $\mathrm{VO}_{2}$ value corresponding to the intersection of two linear regression lines derived separately from the data points below and above the breakpoint in the $\mathrm{VCO}_{2}$ versus $\mathrm{VO}_{2}$, and $\mathrm{VE}$ versus $\mathrm{VCO}_{2}$ relationships, respectively (Figure 1). Additionally, to increase the accuracy of the identification of VT and RCP, a visual identification technique was used as described below. VT was determined using the criteria of an increase in $\mathrm{VE} \mathrm{NO}_{2}$ with no increase in $\mathrm{VE} / \mathrm{NCO}_{2}$ and an increase in end-tidal $\mathrm{O}_{2}$ pressure with no fall in end-tidal $\mathrm{CO}_{2}$ pressure, whereas $\mathrm{RCP}$ corresponded to an increase in $\mathrm{VE} / \mathrm{VCO}_{2}$ and decrease in end-tidal $\mathrm{CO}_{2}$ pressure. To reduce the variability connected with the identification of $\mathrm{VT}$ and $\mathrm{RCP}$, analyses were performed by two independent investigators. If there was disagreement, the opinion of a third investigator was sought. Each of the following variables was recorded at both the $V T$ and the $\mathrm{RC}$; running speed $(\mathrm{km} / \mathrm{h}), \mathrm{VO}_{2}(\mathrm{ml} / \mathrm{kg} / \mathrm{min})$ and $\mathrm{VO}_{2}$ as a percentage of $\mathrm{VO} 2 \mathrm{max}\left(\% \mathrm{VO}_{2 \max }\right)$. Linear regression analyses 
A

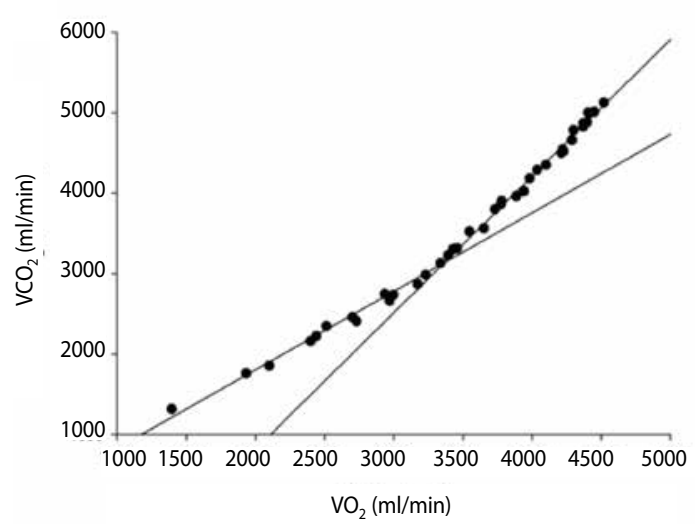

B

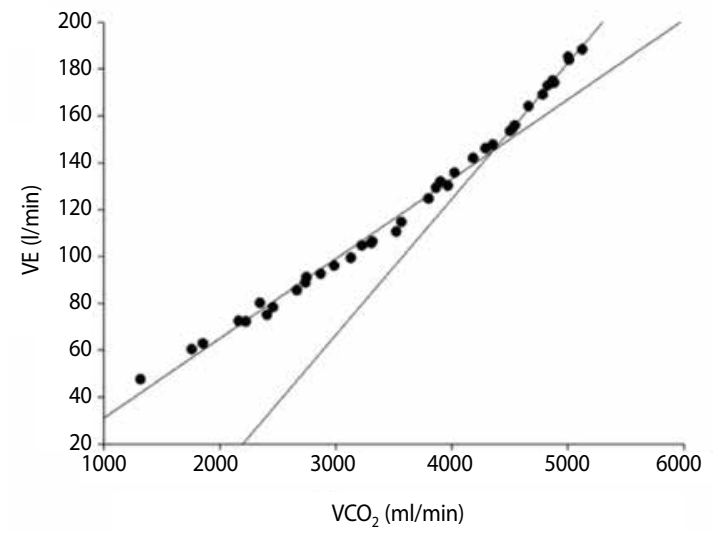

Figure 1. Examples showing methods of determining the ventilatory threshold $(A)$ and the respiratory compensation point (B) in one subject.

were performed by using the Sigma Plot program (Sigma Plot 12.0, Systat Software Inc., Chicago, USA).

ICB phase was calculated as the difference in $\mathrm{VO}_{2}\left(\mathrm{ICB}_{\mathrm{VO} 2}\right)$ and running speed (ICB $\left.{ }_{\text {SPEED }}\right)$ between RCP and $\mathrm{VT}^{7}$, and expressed in either absolute or relative values (expressed as a percentage of RCP previously described by Rocker et al..). ${ }^{11} \mathrm{HHV}$ phase was calculated as the difference in VO2 $\left(\mathrm{HHV}_{\mathrm{VO} 2}\right)$ and running speed $\left(\mathrm{HHV}_{\mathrm{SPEED}}\right)$ between the end of exercise and $\mathrm{RCP}^{7}$ and expressed in either absolute or relative values (expressed as a percentage of $\mathrm{VO}_{2 \max }$ and maximal running speed).

During the six-week training period, the players in both groups continued their regular volleyball training program. Volleyball training for the development of technical and tactical skills was the same in both groups. The main part of the volleyball session included serving, passing, and setting in small groups, blocking and spiking technique, small-sided games to work on offensive and defensive strategies, and individual tactics.

The RST was performed three times per week immediately before the volleyball training session. ${ }^{10}$ Details of the weekly RST program are given in Table 1. The RST consisted of 1-3 sets of 3-5 × 20-m maximal sprints with 20 $s$ of active recovery between sprints and 4 min of passive recovery between sets. Each sprint represents a maximal effort with 20 s allowed between each sprint for the turnaround. The recovery time was controlled by a hand-held stopwatch. Training volume was progressively increased over 6 weeks.

\section{Statistical analysis}

Data are reported as means \pm standard deviation (SD). Statistical significance was accepted at $p<0.05$. The normality of the data was examined by assessing the Shapiro-Wilk test on all measured variables. The differences in all baseline measures between EXG and CG were evaluated by the unpaired t-test for normally distributed data, and Mann-Whitney $U$ test for non-normally distributed data. Within-group changes before and after the 6-week training period was compared using paired t-test for normally distributed data, and Wilcoxon matched-pair signed-rank test for non-normally distributed data.

\section{RESULTS}

There were no significant differences between the two groups for age, height, body mass and the baseline physiological variables ( $p>0.05$, Table 2). After the training period maximal running speed, the time to exhaustion, $\mathrm{VO}_{2 \max }$ and $\mathrm{RER}_{\max }$ during the incremental treadmill test were increased in the EXG ( $p<0.01$, Table 2). There were no significant changes in values of $\mathrm{VO}_{2}$ and running speeds corresponding to $\mathrm{VT}$, and $\mathrm{VT}$ expressed as $\% \mathrm{VO}_{2 \max }$ after training in the experimental group ( $p>0.05$ ). The EXG showed a significant increase in values of $\mathrm{VO}_{2}$ and running speeds corresponding to $\mathrm{RCP}$, and $\mathrm{RCP}$ expressed as $\% \mathrm{VO}_{2 \max }$ after training $(\mathrm{p}<0.01)$.
Table 1. The 6 weeks of RST program, showing the number of sets and repetitions for each session.

\begin{tabular}{|c|c|c|c|c|c|}
\hline Week & Session & Number of sets & \multicolumn{3}{|c|}{ Repetitions $\times$ Distance $(\mathrm{m})$} \\
\hline \multirow{3}{*}{1} & 1 & 1 & $5 \times 20$ & & \\
\hline & 2 & 1 & $5 \times 20$ & & \\
\hline & 3 & 1 & $5 \times 20$ & & \\
\hline \multirow{3}{*}{2} & 4 & 2 & $5 \times 20$ & $3 \times 20$ & \\
\hline & 5 & 2 & $5 \times 20$ & $3 \times 20$ & \\
\hline & 6 & 2 & $5 \times 20$ & $3 \times 20$ & \\
\hline \multirow{3}{*}{3} & 7 & 2 & $5 \times 20$ & $5 \times 20$ & \\
\hline & 8 & 2 & $5 \times 20$ & $5 \times 20$ & \\
\hline & 9 & 2 & $5 \times 20$ & $5 \times 20$ & \\
\hline \multirow{3}{*}{4} & 10 & 2 & $5 \times 20$ & $5 \times 20$ & \\
\hline & 11 & 2 & $5 \times 20$ & $5 \times 20$ & \\
\hline & 12 & 2 & $5 \times 20$ & $5 \times 20$ & \\
\hline \multirow{3}{*}{5} & 13 & 3 & $5 \times 20$ & $5 \times 20$ & $5 \times 20$ \\
\hline & 14 & 3 & $5 \times 20$ & $5 \times 20$ & $5 \times 20$ \\
\hline & 15 & 3 & $5 \times 20$ & $5 \times 20$ & $5 \times 20$ \\
\hline \multirow{3}{*}{6} & 16 & 3 & $5 \times 20$ & $5 \times 20$ & $5 \times 20$ \\
\hline & 17 & 3 & $5 \times 20$ & $5 \times 20$ & $5 \times 20$ \\
\hline & 18 & 3 & $5 \times 20$ & $5 \times 20$ & $5 \times 20$ \\
\hline
\end{tabular}

Table 2. Physiological variables corresponding to the ventilator threshold, respiratory compensation point, maximal values, isocapnic buffering and hypocapnic hyperventilation phases of the experimental and control groups baseline and after the 6 weeks training period.

\begin{tabular}{|c|c|c|c|c|c|c|}
\hline \multirow[t]{2}{*}{ Variables } & \multicolumn{3}{|c|}{ Experimental Group $(n=9)$} & \multicolumn{3}{|c|}{ Control Group $(n=9)$} \\
\hline & Baseline & $\begin{array}{c}\text { After } \\
\text { training }\end{array}$ & p & Baseline & $\begin{array}{c}\text { After } \\
\text { training }\end{array}$ & $p$ \\
\hline $\mathrm{VO}_{2 V T}$ & $37.7 \pm 5$ & $39.6 \pm 5.5$ & 0.07 & $38.6 \pm 5.3$ & $39.9 \pm 6.1$ & 0.09 \\
\hline $\mathrm{VT} \% \mathrm{VO}_{2 \max }$ & $75.2 \pm 6.9$ & $74 \pm 9$ & 0.19 & $74.9 \pm 8$ & $77.5 \pm 9.7$ & 0.1 \\
\hline Speed $_{V T}$ & $10.7 \pm 1.4$ & $11 \pm 1.6$ & 0.68 & $10.7 \pm 1.1$ & $11.1 \pm 1.2$ & 0.31 \\
\hline $\mathrm{VO}_{2 \mathrm{RCP}}$ & $43 \pm 5.1$ & $47.8 \pm 3.4^{*}$ & 0.008 & $44.7 \pm 4.7$ & $44.9 \pm 5.1$ & 0.41 \\
\hline $\mathrm{RCP} \% \mathrm{VO}_{2 \max }$ & $85.7 \pm 4.8$ & $89.3 \pm 4.8^{*}$ & 0.007 & $86.7 \pm 5.9$ & $87.1 \pm 6.4$ & 0.1 \\
\hline Speed $_{\text {RCP }}$ & $13.1 \pm 1.3$ & $14.6 \pm 1.3^{*}$ & 0.001 & $13.2 \pm 1.4$ & $13.5 \pm 1.4$ & 0.17 \\
\hline $\mathrm{VO}_{2 \max }$ & $50 \pm 3.6$ & $53.4 \pm 1.8^{*}$ & 0.001 & $50.4 \pm 4$ & $50.6 \pm 4$ & 0.4 \\
\hline Speed $_{\max }$ & $15.6 \pm 1.3$ & $16.8 \pm 1^{*}$ & 0.001 & $15.6 \pm 1.1$ & $16 \pm 1.1$ & 0.08 \\
\hline Time to ex & $8.93 \pm 1.3$ & $10.27 \pm 1.1$ & 0.004 & $8.80 \pm 1.1$ & $9.07 \pm 1.2$ & 0.11 \\
\hline $\mathrm{RER}_{\max }$ & $1.16 \pm 0.04$ & $1.23 \pm 0.04$ & 0.01 & $1.17 \pm 0.06$ & $1.17 \pm 0.05$ & 0.85 \\
\hline$A b s \mid C_{\text {VO2 }}$ & $5.2 \pm 2.2$ & $8.1 \pm 3.1^{*}$ & 0.005 & $6.1 \pm 1.9$ & $4.9 \pm 2.3$ & 0.09 \\
\hline RellCB ${ }_{\mathrm{VO} 2}$ & $12.2 \pm 4.7$ & $17.2 \pm 6.9^{*}$ & 0.01 & $13.8 \pm 4.4$ & $11.3 \pm 5.7$ & 0.12 \\
\hline $\mathrm{Abs} \mathrm{CB}_{\text {SPEED }}$ & $2.3 \pm 0.5$ & $3.6 \pm 1^{*}$ & 0.01 & $2.5 \pm 0.5$ & $2.3 \pm 0.9$ & 0.65 \\
\hline RellCB $B_{\text {SPEED }}$ & $17.9 \pm 4.2$ & $25.1 \pm 6.7^{*}$ & 0.005 & $18.7 \pm 2.8$ & $17.4 \pm 6.2$ & 0.25 \\
\hline $\mathrm{AbsHHV}_{\mathrm{VO2}}$ & $7 \pm 2$ & $5.6 \pm 2.4^{*}$ & 0.02 & $6.7 \pm 2.9$ & $6.5 \pm 3.2$ & 0.51 \\
\hline $\mathrm{RelHHV}_{\mathrm{VO} 2}$ & $14.2 \pm 4.8$ & $10.6 \pm 4.8^{*}$ & 0.007 & $13.2 \pm 5.9$ & $12.8 \pm 6.4$ & 0.48 \\
\hline AbsHHV & $2.5 \pm 0.8$ & $2.2 \pm 0.6$ & 0.18 & $2.3 \pm 1$ & $2.5 \pm 0.5$ & 0.65 \\
\hline RelHHV & $16.2 \pm 5.2$ & $13.2 \pm 4.2$ & 0.053 & $15.2 \pm 6.9$ & $15.7 \pm 3.8$ & 0.76 \\
\hline
\end{tabular}


Both absolute and relative values of $\mathrm{ICB}_{\mathrm{VO} 2}$ and $\mathrm{ICB}_{\text {SPEED }}$ were significantly increased in the EXG after training $(p<0.01)$. The both absolute and relative $\mathrm{HHV}_{\text {VO2 }}$ were significantly reduced in the EXG $(p<0.05)$, while the absolute and relative $H H V_{\text {SPEED }}$ were unchanged after 6-week training ( $\left.p>0.05\right)$. None of these variables were significantly changed in the CG ( $p>0.05)$.

\section{DISCUSSION}

The results of this study indicated that the RST program led to a significant improvement in ICB phase, $\mathrm{RCP}$ and $\mathrm{VO}_{2 \max }$ in the EXG while no change occurred in the VT. None of these variables were significantly changed in the CG after the training program, suggesting that volleyball training alone may not suffice for the improvement of buffering capacity. Our findings suggest that RST might have been improved the buffering capacity leading to a shift of RCP to higher intensities and improve high-intensity exercise tolerance, and consequently enhancing the ICB phase.

No significant change was observed in the VT of the EXG, whereas improved in $\mathrm{RCP}$ and $\mathrm{VO}_{2 \text { max }}$. Consistent with our results, previous studies have shown that no significant change in AT after maximal sprint interval training, whereas improve in $\mathrm{VO}_{2 \text { max }}{ }^{12,13}$ In contrast, some studies have demonstrated that AT may improve without changes in $\mathrm{VO}_{2 \max }$ after the endurance training ${ }^{14}$ and over the football season. ${ }^{15}$ Although both $\mathrm{VO}_{2 \max }$ and AT are the most important physiological variables associated with aerobic performance, the two variables appear to have different physiological mechanisms. It has been suggested that lower intensity training at slightly below AT improves AT and induces mainly central adaptations such as improvements in pulmonary diffusion, hemoglobin affinity, and increases in cardiac output. ${ }^{16}$ On the other hand, higher intensity training at $\mathrm{VO}_{2 \max }$ induces mainly peripheral adaptations, which provide the improvement of $\mathrm{VO}_{2 \max }$ such as increases in oxidative enzyme activity, mitochondrial volume and density, and myoglobin. ${ }^{16} \mathrm{It}$ has been shown that sprint interval training induces specific metabolic adaptations leading to increase in $\mathrm{VO}_{2 \max }{ }^{17}$ Our findings suggest that RST can be effective in enhancing $\mathrm{VO}_{2 \max }$ but not $\mathrm{VT}$; this may have been due to the maximal intensity of the training sessions.

Our findings demonstrate that the repeated sprint training represents an effective means of increasing RC rather than VT. Oshima at al.? has shown that endurance training above the AT more effective in increasing the RCP than in increasing VT. The longer ICB phase observed in EXG after training may associate with shift of RCP to higher intensities. RST sessions might have been improved the buffering capacity leading to a shift in RCP. It has been suggested that the individual difference in RCP depends partly on the chemosensitivity of the carotid bodies and the rate of lactic acid increase during exercise. ${ }^{18}$ The higher RCP and therefore longer ICB phase recorded after training in EXG which may be due to lower sensitivity of carotid bodies to acute metabolic acidosis. ${ }^{19}$ Regular physical training may reduce the chemosensitivity of the carotid bodies. Miyachi and Katamaya ${ }^{20}$ reported that high intensity interval training result in less hyperventilation during heavy exercise, which may be partly associated to adaptations in ventilator chemoresponses. On the other hand, in our study, the increase in maximal running speed and running time to exhaustion without changes in running speed corresponding to VT after training may demonstrates that improved high-intensity exercise tolerance and the buffering capacity. The EXG was able to continue to exercise for longer periods of time above the VT during the incremental treadmill test after training.

In the EXG, the higher RER $_{\max }$ recorded after the RST, which may have been due to the longer exercise time above the VT. Although we could not directly measure blood lactate levels, the increase in $\mathrm{RER}_{\max }$ may reflect a greater accumulation of lactate after the RST. ${ }^{21}$ It has been shown that the sprint training led to a greater accumulation of lactate both in the muscle and blood during exhaustive exercise. ${ }^{22,23}$ These higher lactate concentrations after sprint training may be explained by the increase of the muscle buffer capacity and glycolytic enzymes.22,23 A large accumulation of lactate and $\mathrm{H}^{+}$during high intensity exercise may provide an important stimulus for adaptations of the muscle $\mathrm{pH}$ regulating systems. ${ }^{24,25}$

It has been shown that athletes with high $\mathrm{VO}_{2 \max }$ have longer ICB phase than athletes with low $\mathrm{VO}_{2 \max }{ }^{6}$ On the other hand, recently it has been shown that the relative ICB phase can be useful for predict both the aerobic and anaerobic capacity in the athletes. ${ }^{26}$ The studies that address ICB phase in relation to physical training are scarce. $5,7,27$ The increase in ICB phase with concomitant improvement in aerobic capacity after RST in the present study is consistent with the findings of Oshima at al. ${ }^{7}$ These authors have reported the absolute ICB phase in runners significantly increased after endurance training above the AT.? They observed that the increase in the RCP is larger than that of VT after 6-month training period. In contrast, Chicharro at al. ${ }^{5}$ have reported that both the absolute and relative ICB phase and $\mathrm{VO}_{2 \text { max }}$ in professional cyclists remained unchanged throughout the season despite a considerable increase in training loads. Several studies have shown that the longer relative ICB phase in sprint-trained athletes than in endurance athletes. ${ }^{11,19,26}$ According to Chicharro at al., ${ }^{5}$ intense training sessions involving anaerobic metabolism improves the buffering capacity leading to a shift in RCP towards higher intensities, and consequently extending the ICB phase. On the other hand, training sessions involving aerobic metabolism may induces a similar shift in both VT and RCP. Therefore, it appears that effect of the high intensity training sessions RC may greater than AT. During the ICB phase, more $\mathrm{H}^{+}$has been reported buffered by the non-bicarbonate buffer system in sprint-trained cyclists than in endurance cyclists. ${ }^{26}$ Sprint training has been reported to increase the muscle buffer capacity, whereas endurance training had no effect. ${ }^{22}$ We used a training program based on RST. ${ }^{28}$ Likely, the incomplete recoveries which characterize RST contribute to the aerobic adaptation of the muscle. ${ }^{29} \mathrm{It}$ is, therefore, possible that, the increase in ICB phase noted in this study could be the result of the enhanced both bicarbonate and non-bicarbonate buffering capacity.

The HHV phase reduced significantly in the EXG after RST when expressed as $\mathrm{VO}_{2}$, but not as running speed. Chicharro at al. ${ }^{5}$ have shown that the increase in RCP leading to a shortening of the HHV phase over the season whereas remained unchanged in $\mathrm{VO}_{2 \text { max }}$. In contrast, Oshima at al. ${ }^{7}$ have been reported that no significant change in the HHV phase after training, whereas improved in ICB phase, $\mathrm{RCP}$ and $\mathrm{VO}_{2 \text { max }}$. Many studies have shown that the HHV phase is not correlated with $\mathrm{VO}_{2 \text { max }}{ }^{6,27}$ Thus it seems likely that the HHV phase is not related to exercise capacity. 7,30

\section{CONCLUSION}

From these results, we conclude that repeated sprint training can enhance the ICB phase of volleyball players which may be attributable to improve of the buffering capacity leading to shift of RCP to higher intensities without any change in VT. The increase in the ICB phase may an important factor in relation to the improvement in the high-intensity exercise tolerance in athletes.

All authors declare no potential conflict of interest related to this article.

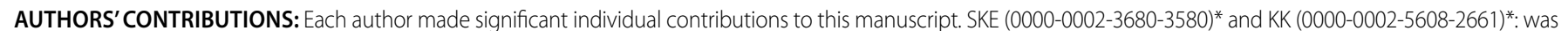
responsible for data collection, data analysis and interpretation, and the writing of the draft; MP (0000-0001-7299-0531)*: helped in data analysis and interpretation; SA (00000003-3230-5864)*: designed the study and supervised the data collection, analysis, and supervised the writing of the manuscript. All authors read and approved the final manuscript. *ORCID (Open Researcher and Contributor ID). 


\section{REFERENCES}

1. Beaver WL, Wasserman K, Whipp BJ. A new method for detecting the anaerobic threshold by gas exchange. J Appl Physiol (1985). 1986;60(6):2020-7.

2. Wasserman K. The anaerobic threshold measurement to evaluate exercise performance. Am Rev Respir Dis. 1984;129(2 Pt):35-40

3. Meyer T, Faude O, Scharhag J, Urhausen A, Kindermann W. Is lactic acidosis a cause of exercise induced hyperventilation at the respiratory compensation point? Br J Sports Med. 2004;38(5):622-5.

4. Whipp BJ, Davis JA, Wasserman K. Ventilatory control of the 'isocapnic buffering' region in rapidly -incremental exercise. Respir Physiol. 1989;76(3):357-67.

5. Chicharrro J, Hoyos J, Lucia A. Effects of endurance training on the isocapnic buffering and hypocapnic hyperventilation phases in Professional cyclists. Br J Sports Med. 2000;34(6):450-5.

6. Oshima Y, Miyamoto T, Tanaka S, Wadazumi T, Kurihara N, Fujimoto S. Relationship between isocapnic buffering and maximal aerobic capacity in athletes. Eur J Appl Physiol Occup Physiol. 1997;76(5):409-14

7. Oshima Y, Tanaka S, Miyamoto T. Effects of endurance training above the anaerobic threshold on isocapnic buffering phase during incremental exercise in middle-distance runners. Jpn J Phys Fitnes Sports Med. 1998;47(1):43-52

8. Bravo DF, Impellizzeri FM, Rampinini E, Castagna C, Bishop D, Wisloff U. Sprint vs. interval training in football. Int J Sports Med. 2008;29(8):668-74.

9. Farzad BR, Gharakhanlou H, Agha-Alinejad DG, Curby M, Bayati M, Bahraminejad M, et al. Physiologica and performance changes from the addition of a sprint-interval program to wrestling training. J Strength Cond Res. 2011:25(9):2392-9.

10. Kaynak K, Korkmaz Eryılmaz S, Aydoğan S, Mihailov D. The effects of 20-m repeated sprint training on aerobic capacity in college volleyball players. Biomed Hum Kinetics. 2017;9(1):43-50.

11. Röcker K, Striegel H, Freund T, Dickhuth HH. Relative functional buffering capacity in 400-meter runners, long-distance runners and untrained individuals. Eur J Appl Physiol Occup Physiol. 1994;68(5):430-4.

12. Bailey SJ, Wilkerson DP, DiMenna FJ, Jones AM. Influence of repeated sprint training on pulmonary O2 uptake and muscle deoxygenation kinetics in humans. J Appl Physiol (1985). 2009;106(6):1875-87.

13. Esfarjani F, Laursen PB. Manipulating high-intensity interval training: Effects on 'VO2max, the lactate threshold and 3000m running performance in moderately trained males. J Sci Med Sport. 2007;10(1):27-35

14. Fouquet R, Poty P. Effect of 40 weeks of endurance training on anaerobic threshold. Int J Sports Med 1982;3(4):208-14

15. Edwards AM, Clark N, Macfadyen AM. Lactate and ventilatory thresholds reflect the training status of professional soccer players where maximum aerobic power is unchanged. J Sports Sci Med. 2003;2(1):23-9.
16. Docherty D, Sporer B. A proposed model for examining the interference phenomenon between concurrent aerobic and strength training. Sports Med. 2000;30(6):385-94

17. Burgomaster KA, Howarth KR, Phillips SM, Rakobowchuk M, MacDonald MJ, McGee SL, el al. Similar metabolic adaptations during exercise after low volume sprint interval and traditional endurance training in humans. J Physiol. 2008;586(1):151-60.

18. Takano N. Respiratory compensation point during incremental exercise as related to hypoxic ventilator chemosensitivity and lactate increase in man. Jpn J Physiol. 2000;50(4):449-55.

19. Hirakoba $K$, Yunoki T. Blood lactate changes during isocapnic buffering in sprinters and long distance runners. J Physiol Anthropol Appl Human Sci. 2002;21(3):143-9.

20. Miyachi M, Katayama K. Effects of maximal interval training on arterial oxygen desaturation and ventilation during heavy exercise. Jpn J Physiol. 1999;49(5):401-7.

21. Stringer W, Wasserman K, Casaburi R. The VCO2/NO2 relationship during heavy, constant work rate exercise reflects the rate of lactic acid accumulation. Eur J Appl Physiol Occup Physiol. 1995;72(1):25-31

22. Sharp RL, Costill DL, Fink WJ, King DS. Effects of eight weeks of bicycle ergometer sprint training on human muscle buffer capacity. Int J Sports Med. 1986;7(1):13-7.

23. Mohr M, Krustrup P, Nielsen JJ, Nybo L, Rasmussen MK, Juel C, et al. Effect of two different intense training regimens on skeletal muscle ion transport proteins and fatigue development. Am J Physiol Regul Integ Comp Physiol. 2007;292(4):1594-1602.

24. Bishop D, Girard O, Mendez-Villanueva A. Repeated-Sprint Ability Part Il: Recommendations for Training Sports Med. 2011:41(9):741-56.

25. Edge J, Bishop D, Goodman C. The effects of training intensity on muscle buffer capacity in females Eur J Appl Physiol. 2006:96(1):97-105.

26. Hasanli M, Nikooie R, Aveseh M, Mohammad F. Prediction of aerobic and anaerobic capacities of elite cyclists from changes in lactate during isocapnic buffering phase. J Strength Cond Res. 2015;29(2):321-9.

27. Lenti M, De Vito G, Scottodi Palumbo A, Sbriccoli P, Quattrini FM, Sacchetti M. Effects of aging and training status on ventilatory response during incremental cycling exercise. J Strength Cond Res. 2011;25(5):1326-32

28. Buchheit M, Laursen PB. High-intensity interval training, solutions to the programming puzzle: Part 1: cardiopulmonary emphasis. Sports Med. 2013;43(5):313-38.

29. Barnett C, Carey M, Proietto J, Cerin E, Febbraio MA, Jenkins D. Muscle metabolism during sprint exercise in man: influence of sprint training. J Sci Med Sport. 2004;7(3):314-22.

30. Bentley DJ, VleckVE, Millet GP. The isocapnic buffering phase and mechanical efficiency: Relationship to cycle time trial performance of short and long duration. Can J Appl Physiol. 2005;30(1):46-60. 